\title{
The multidisciplinary surgical center team's response to the COVID-19 pandemic
}

\author{
O enfrentamento da equipe multidisciplinar do centro cirúrgico diante da pandemia da COVID-19 \\ El enfrentamiento del equipo multidisciplinar del centro quirúrgico frente a la pandemia de la COVID-19
}

Ana Karina Silva da Rocha Tanaka'
ORCID: 0000-0003-2488-3656

Liege Segabinazzi Lunardi'

ORCID: 0000-0001-8416-8529

Flávia Giendreuczak da Silva" ORCID: 0000-0003-4223-4772

Liziane Medianeira Calegari Rigon Gil"I ORCID:0000-0002-6788-968X

'Universidade Federal do Rio Grande do Sul. Porto Alegre, Rio Grande do Sul, Brazil.

"Centro Universitário Metodista. Porto Alegre, Rio Grande do Sul, Brazil.

III Universidade Federal de Santa Maria. Santa Maria Rio Grande do Sul, Brazil.

How to cite this article:

Tanaka AKSR, Lunardi LS, Silva FG, Gil LMCRS. The multidisciplinar surgical center team's response to the COVID-19 pandemic

Rev Bras Enferm. 2020;73(Suppl 2):e20200333. doi: http://dx.doi.org/10.1590/0034-7167-2020-0333

Corresponding author:

Ana Karina Silva da Rocha Tanaka E-mail: ana.tanaka@ufrgs.br

EDITOR IN CHIEF: Dulce Barbosa ASSOCIATE EDITOR: Andrea Bernardes

Submission: $04-28-2020$

Approval: 09-13-2020

\section{ABSTRACT}

Objective: Report on the implementation of assistance protocols in the face of the COVID-19 pandemic developed in the surgical center of a large university hospital in Rio Grande do Sul. Method: Experience report on the implementation of paramentation and deworming assistance protocols by the multidisciplinary surgical center team in the fight against the COVID-19 pandemic, at a large university hospital in Rio Grande do Sul, held between March and April 2020. Results: In the confrontation of the pandemic by the multidisciplinary team of the surgical center, the activities adopted in the development of its action plan were described in two moments. The multiprofessional team carried out educational training on the process of paramentation and deworming as well as the preparation of professionals in the care of the patient COVID-19. Conclusion: With the established routines and a large number of trained professionals, it was possible to observe a better preparation of the multidisciplinary team in face of the needs imposed by the new coronavirus.

Descriptors: Coronavirus; Surgical Centers; Patient Care Team, Personal Protective Equipment, Inservice Training.

\section{RESUMO}

Objetivo: Relatar a implantação de protocolos assistenciais diante da pandemia da COVID-19 desenvolvidos no centro cirúrgico de um hospital universitário de grande porte no Rio Grande do Sul. Método: Relato de experiência sobre a implantação de protocolos assistenciais de paramentação e desparamentação da equipe multidisciplinar do centro cirúrgico no enfrentamento da pandemia da COVID-19, em um hospital universitário de grande porte no Rio Grande do Sul realizado entre março e abril de 2020. Resultados: No enfrentamento da pandemia pela equipe multidisciplinar do centro cirúrgico, descreveram-se em dois momentos as atividades adotadas no desenvolvimento de seu plano de ação. Realizaram-se capacitações educativas com a equipe multiprofissional quanto ao processo de paramentação e desparamentação bem como ao preparo dos profissionais no atendimento ao paciente COVID-19. Conclusão: Com as rotinas estabelecidas e grande número de profissionais capacitados, foi possível observar um melhor preparo da equipe multidisciplinar perante as necessidades impostas pelo novo coronavírus.

Descritores: Coronavírus; Centros Cirúrgicos; Equipe de Assistência ao Paciente, Equipamento de proteção individual, Capacitação em Serviço.

\section{RESUMEN}

Objetivo: Relatar implantación de protocolos asistenciales ante la pandemia COVID-19 desarrollados en el centro quirúrgico de un hospital universitario en Rio Grande do Sul. Método: Relato de experiencia sobre la implantación de protocolos asistenciales de paramentación y desparamentación del equipo multidisciplinar del centro quirúrgico en el enfrentamiento a la pandemia COVID-19, en un hospital universitario en Rio Grande del Sul realizado entre marzo y abril de 2020. Resultados: En el enfrentamiento a la pandemia por el equipo multidisciplinar del centro quirúrgico, describieron en dos momentos las actividades adoptadas en el desarrollo de su plan de acción. Realizaron capacitaciones educativas con el equipo multiprofesional cuanto al proceso de paramentación y desparamentación bien como al preparo de los profesionales a la atención al paciente COVID-19. Conclusión: Con las rutinas establecidas y gran número de profesionales capacitados, observarse un mejor preparo del equipo multidisciplinar delante las necesidades impuestas por el nuevo coronavirus. Descriptores: Coronavirus; Centros Quirúrgico; Equipo de Asistencia al Paciente, Equipo de Protección Personal, Capacitación en Servicio. 


\section{INTRODUCTION}

The surgical center is defined as a closed area next to a set of facilities that is destined to perform anesthetic-surgical procedures. The operating room has a complex hospital structure, composed of technological components, and involves several professionals trained to develop the dynamics of the area. All its equipment and structure facilities follow the safety standards of current legislation, as well as the plans for emergency situations ${ }^{(1)}$.

According to the need to have constant updates and the preparation of the team for the assistance in several situations, assistance protocols with theoretical and practical basis are used. With the appearance of the new coronavirus, a series of measures were created to protect health professionals. The preparation of the care group for patients suspected or diagnosed with the new coronavirus infection has developed through technical norms, guidelines and assistance protocols, building criteria in the surgical process and reinforcing the use of individual protection equipment (PPEs) during the entire period of professional exposure ${ }^{(2)}$. In this sense, the professionals sought training on paramentation and surgical deparation in line with the care for the use of PPEs.

According to the Ministry of Health $(\mathrm{MH})$, the new coronavirus was identified in Wuhan, China, still in December 2019, whose first cases were confirmed in January 2020. It is a virus of the order Nidovirales, from the family Coronaviridae, being highly pathogenic and responsible for causing respiratory and gastrointestinal syndrome. At the beginning of the year, many people were infected; among them, many were health professionals who are in direct care of these patients. The main route of virus transmission is respiratory, through the inhalation of droplets and aerosols from contaminated patients. Precautionary measures in the care of these patients (infected or suspected) should follow the guidelines of current protocols to ensure the safety of the health professional| ${ }^{(3-4)}$.

In the health area, the professionals who act in the procedures of the COVID-19 patients must necessarily use the PPE: N95 mask, facial protector, apron, cap, glove and waterproof shoe protector. Thus, this protection allows a safe assistance to the multidisciplinary team before the aerosols exposure, especially in surgeries with airway exposure, and also during the intubation of these patients ${ }^{(2)}$. All team members who are in attendance must take their clothes off before entering the contaminated environment, complying with the sequence of paramentation and department. It is important that the professional be supervised by another colleague at the time of the department in order to avoid self-contamination, because many studies show that this is a critical moment for the team ${ }^{(3-5)}$.

In view of the current public health scenario, the safety of the professionals who participate in these services must be guaranteed through adequate training on the standard precaution techniques for contact and aerosols, using, in an adequate way, paramentation and deworming, as well as PPEs. It is also necessary to use specific operating rooms with negative pressure to perform the procedures with airway manipulation in suspect and contaminated patients, in order to guarantee the safety of the professionals ${ }^{(6-7)}$.

\section{OBJECTIVE}

Report on the implementation of assistance protocols in face of the COVID-19 pandemic developed in the surgical center of a large teaching hospital in Rio Grande do Sul.

\section{METHODS}

This is an experience report on the creation and implementation of assistance protocols for paramentation and deworming of the multidisciplinary team in a surgical center to face the COVID-19 pandemic at a large university hospital in Rio Grande do Sul. Given the characteristics of COVID-19 and its impact on public health, the actions developed in the hospital institution were carried out in two stages.

In the first moment, a COVID-19 crisis committee was set up involving professors, administrators and professionals from the hospital's multidisciplinary team, whose discussions were made about the implementation flows and protocols related to the exposure of professionals at the time of the surgery. It was considered the alteration of the scale of employees with the decrease of the elective procedures and the evaluation of the emergency surgeries, resulting in the dimensioning of nursing technicians and nurses to other areas of the hospital. The hospital's surgical center has 13 operating rooms with different specialties, and one of these rooms only serves emergency surgeries. Considering the monthly average of 100 surgeries, during the pandemic there was a decrease in scheduling, in order to prevent the spread of cases and contamination of patients and professionals. Thus, the protocol of the institution was followed with the contingency plan developed at the surgical block unit.

At the second moment, the multidisciplinary team's professionals were listened to, assessing feelings, doubts and expectations about the current moment of public health. Realistic simulation training took place, in a practical, dynamic and expository way, with a maximum number of eight people per training, with a distance of 2 meters. The training sessions were held from March to April 2020 by two trained nurses. The trainings contemplated the care with the paramentation and surgical deparation, paying attention to the prevention of professionals regarding self-contamination, based on protocols and referential ${ }^{(5)}$.

At the end of these actions, the institution established the care plan for the patient COVID-19, from the care in the scheduling of the procedure, referral of the patient in the process of recovery anesthetic-surgical, until the removal of the professionals after the care, involving the multidisciplinary team (nurses, nursing technicians, surgeons and anesthesiologists).

\section{RESULTS}

Since the strategies adopted in the institution were divided in two moments and in order to facilitate the understanding of the actions developed in the hospital unit, the reports were categorized in Crisis committee in facing the pandemic and; Experiencing the confrontation of the pandemic through continuing education. 


\section{Crisis committee in facing the pandemic}

Through the COVID-19 crisis committee meetings involving professors, administrators and professionals from the hospital's multidisciplinary team, the new attendance flows, the need for structural adequacy, as well as the implementation of these protocols were discussed, aiming at minimizing the exposure of the professionals at the time of the surgery.

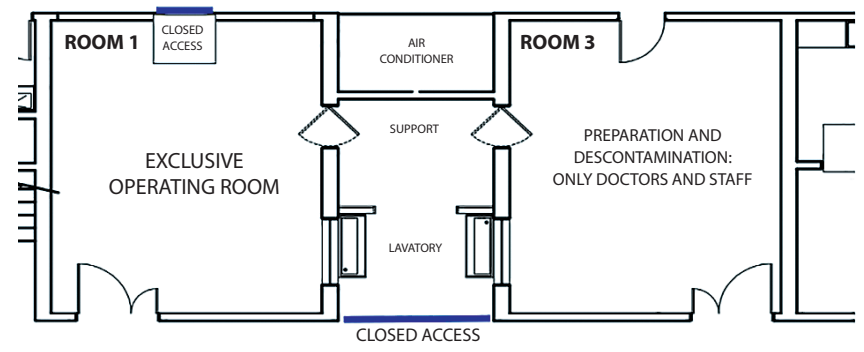

Figure 1 - Organization of the operating room according to hospital protocol

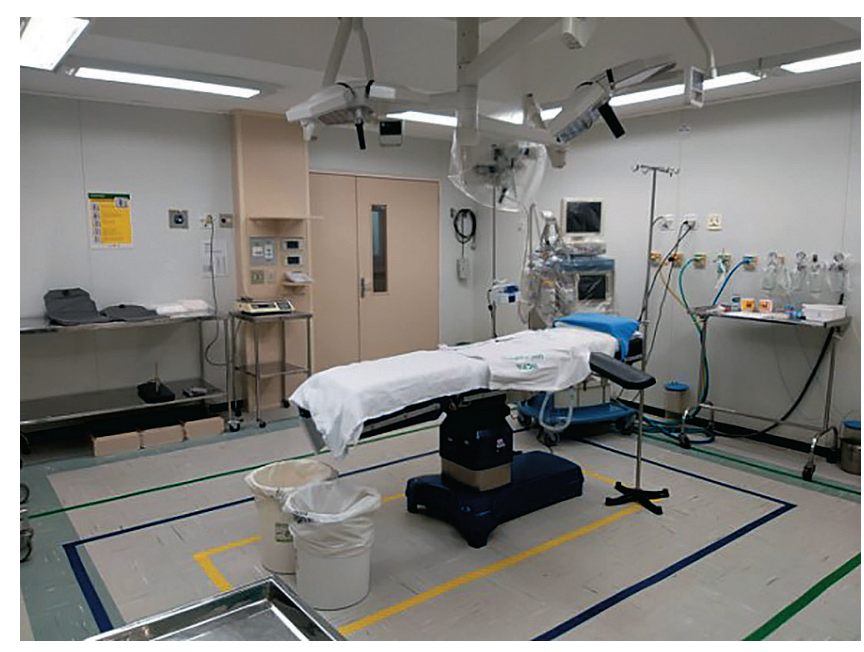

Figure 2- Surgical Room 1, finalized for the servic

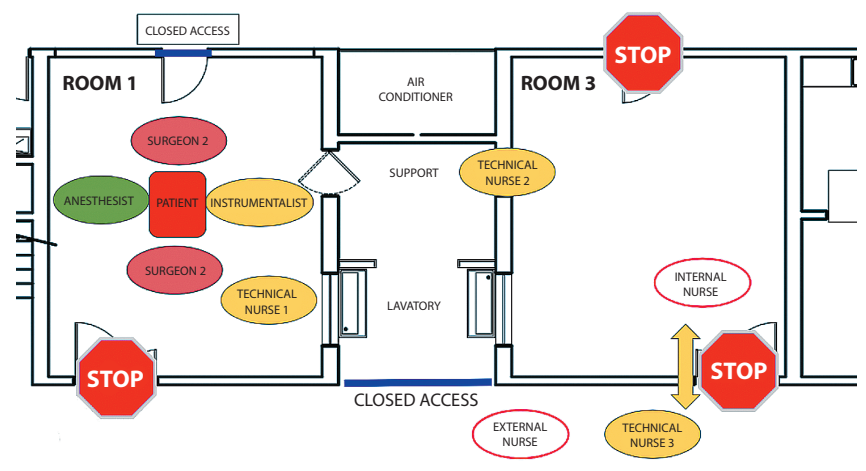

Figure 3 - Patient care flow in the operating room

From this perspective, an action plan was developed to meet the needs of the area, remodeling the structure of the operating room to meet the specificities of the surgical environment. The operating room was redefined near the entrance of the surgical center, in order to facilitate the flow of the area; an air system with negative pressure was also installed there, to avoid the dissemination by aerosols of the new coronavirus in the environment, following the flow plan in Figure $1^{(6)}$. The separate materials and equipment in this room were intended for exclusive use in contaminated patients. The equipment was protected with plastics so that, after the procedure, they were removed for terminal cleaning, ensuring the safety of the patient in the operating room and also of the professionals involved in the process ${ }^{(7)}$.

With the remodeling of the physical area, based on the new recommendations of the Ministry of Health, it was possible to plan the hospital training, according to Figure 2. After the changes, we thought about the team that would be involved in the care (instrumentalist, circulating 1, circulating 2, circulating 3 , nurse, anesthetic team and surgical team), with description in Figure 3. It was also considered the whole process involved, from the scheduling of the procedure to the displacement of the patient for his surgical-anesthesia recovery, as well as the needs and precautions required during this process, reinforcing the indispensability of maintaining a lean condition ${ }^{(6)}$.

\section{Experiencing the Pandemic through Continued Education}

The structural planning and effective training of the health care team have become a challenge for all health care institutions. It was with the purpose of training the professionals who circulate in a surgical center of a referral hospital in the care of patients with suspected or diagnosed infection, that the planning of a training in paramentation and deworming began, since it is a recommendation to avoid potential risks of errors and contamination. The training aimed to initially contemplate the nursing team, however, by request and need of the surgical and anesthetic teams, they were also contemplated, increasing the number of professionals able to care for this group of patients ${ }^{(6-8)}$.

In the period of the training, it was observed an increase of the absenteeism in the surgical area by the nursing team, besides requests of licenses and vacations, all related to the concern with the new coronavirus. Thus, the training came to meet the need to promote clarification and safety in the team during the process of care $^{(6,9-10)}$. Therefore, a bibliographic search was made regarding the new coronavirus and the precautionary measures that should be taken, in order to identify new needs and risks of exposure of professionals, simultaneously with the group of the hospital responsible for planning the area. The professionals were guided and trained as to the paramentation and surgical deparation for this service, besides receiving the information about the alteration of the routine of receiving and referral of the patient and the new structural alterations of the operating room. It was reinforced the importance that, during the process of deworming, they would count with the presence of a professional to supervise the removal of PPE, in order to avoid self-contamination and ensure the safety of the team, since this is a time of high risk ${ }^{(8)}$.

The trainings were performed in all shifts and with diverse schedules during three consecutive weeks, in order to involve 237 professionals in the surgical area. It is noteworthy that many of the professionals participated more than once, in order to improve the fixation of learning by relating theory to practice (Chart 1). The trainings took place through practical demonstration of paramentation and deworming and were ministered by nurses of the area. 
Chart 1 - Representation of the training sequence

\begin{tabular}{|c|c|}
\hline Flow and Paramentation & De-paramentation \\
\hline $\begin{array}{l}\text { 1. Presentation of the areas } \\
\text { intended for the care of patients } \\
\text { suspected or diagnosed with the } \\
\text { new coronavirus infection and } \\
\text { scheduling and admission flow; }\end{array}$ & $\begin{array}{l}\text { 8. Reinforcement of the need } \\
\text { to follow the department } \\
\text { checklist displayed on an } \\
\text { illustrative poster in the } \\
\text { designated room; }\end{array}$ \\
\hline $\begin{array}{l}\text { 2. Orientation of the established } \\
\text { perioperative routine; } \\
\text { 3. Presentation of PPE for the } \\
\text { service; }\end{array}$ & $\begin{array}{l}\text { 9. Observation of trained } \\
\text { professional for guidance } \\
\text { and/or assistance in case of } \\
\text { self-contamination; }\end{array}$ \\
\hline $\begin{array}{l}\text { 4. Orientation of the correct use of } \\
\text { PPE items; }\end{array}$ & $\begin{array}{l}\text { 10. Demonstration and } \\
\text { orientation of the step by }\end{array}$ \\
\hline $\begin{array}{l}\text { 5. Demonstration of the step } \\
\text { by step of the paramentation } \\
\text { aiming at the inexistence of } \\
\text { failures; }\end{array}$ & $\begin{array}{l}\text { step department; } \\
\text { 11. Reinforcement of the } \\
\text { importance of hand } \\
\text { sanitizing with alcoholic }\end{array}$ \\
\hline $\begin{array}{l}\text { 6ollow-up of the checklist } \\
\text { displayed in the preparation } \\
\text { room for the paramentation; }\end{array}$ & $\begin{array}{l}\text { solution or water and soap } \\
\text { as recommended in the pre- } \\
\text { established checklist; }\end{array}$ \\
\hline $\begin{array}{l}\text { 7. Clarification of possible doubts } \\
\text { and evaluation of suggestions } \\
\text { for improvement of the } \\
\text { established process; }\end{array}$ & $\begin{array}{l}\text { 12. Recommend the } \\
\text { professionals' bath after } \\
\text { exposure. }\end{array}$ \\
\hline
\end{tabular}

Chart 2 - The steps of paramentation and department of the multidisciplinary team

\begin{tabular}{|c|c|}
\hline Paramentation & De-Paramentation \\
\hline $\begin{array}{l}\text { 1. N95 mask; } \\
\text { 2. Hand hygiene; } \\
\text { 3. Goggles of protection } \\
\text { or personal (of } \\
\text { degree); } \\
\text { 4. Cap, covering all the } \\
\text { hair and ears and rods } \\
\text { of the glasses; } \\
\text { 5. Face protector (face } \\
\text { mask); } \\
\text { 6. Second cap (cap, } \\
\text { protecting elastics of } \\
\text { the facial protector) }{ }^{(9)} \text {; } \\
\text { 7. Waterproof shoe } \\
\text { protector; } \\
\text { 8. Hand hygiene; } \\
\text { 9. Waterproof apron; } \\
\text { 10. Surgical glove, } \\
\text { covering fist } \\
\text { completely; } \\
\text { 11. Second pair of gloves } \\
\text { (can be surgical or } \\
\text { procedure, according } \\
\text { to the professional's } \\
\text { function) }\end{array}$ & 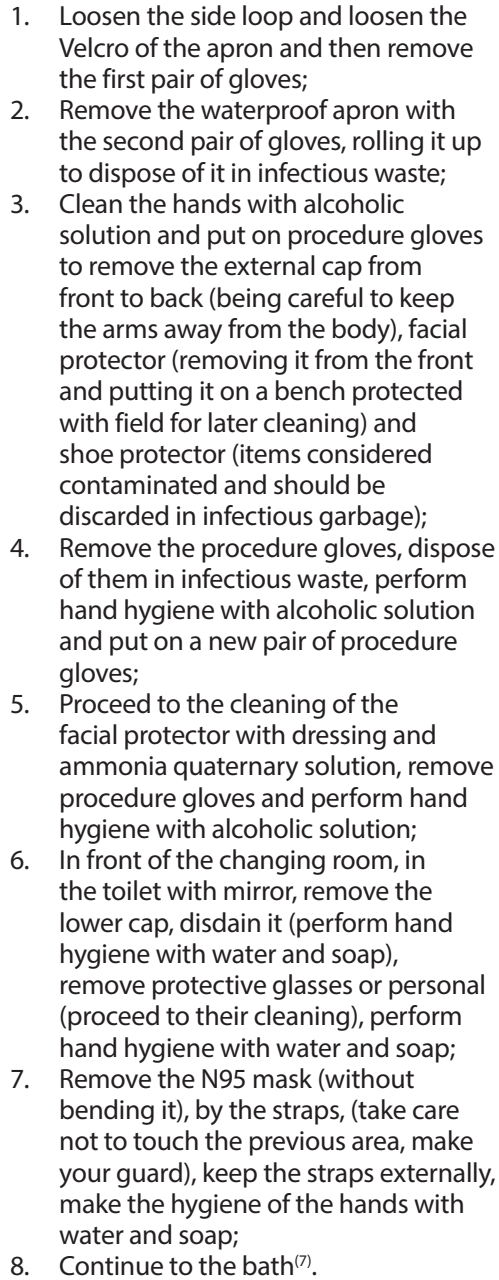 \\
\hline
\end{tabular}

The PPEs used to face the new coronavirus were the N95 mask (in the procedures with aerosol production) or surgical mask, face protector (in the procedures with aerosol production) since it performs the protection of the eyes, avoiding contamination of N95 Mask or goggles (the use of both can help prevent conjunctive exposure of the spray around the facial protector), cap, waterproof apron, surgical gloves that cover the wrist completely (adhesive strips can help maintain the gloves, and the use of a second glove is advised) and shoe covers ${ }^{(6-10)}$. The importance of the care with the N95 mask and the possibility of its reuse (if in conditions), due to its worldwide scarcity and its adequate use without another surgical mask under it, following the attendance protocols, is also reinforced ${ }^{(2)}$ (Chart 2).

At all times, the importance of hand hygiene was emphasized, so that it is the most effective measure to minimize the spread of the virus and self-contamination, either between professionals or between patient and professional or professional and patient, before and after the removal of gloves ${ }^{(5-6)}$.

\section{Study limitations}

The limitations are summarized in the amount of PPE (N95 mask, facial protector, waterproof apron) during the training due to the lack of medical-hospital material; in the availability of professionals for training with time limitation; and in the people in training room respecting the distance.

\section{Contributions to the area of Nursing, Health or Public Policy}

Considering this public health problem that is affecting the population worldwide, it is believed that the present study is relevant for serving as a guide for other institutions to implement strategies/ action plans in the surgical center units in order to minimize the exposure of the multiprofessional team to the risks of self-contamination during the patient's care in the surgical center. It will also contribute both to reducing the statistics of contaminated professionals during deworming and to the emotional balance of the multiprofessional team that is dealing with this problem at the forefront.

The contribution of this report is related to the experience of the multidisciplinary team in the face of the pandemic, seeking to strengthen and raise awareness of protection through a good work of prevention and control, targeting patients, their families and the hospital community. Moreover, this work helps to mitigate psychological fragility in face of the unknown by professionals, especially those with comorbidities, who may be more vulnerable in the hospital environment.

\section{CONCLUSION}

The new coronavirus has brought immediate changes in public health, whether in the care process or in the expectations of professionals who are in the front line. The observations reported in the study contributed to the care of the multidisciplinary team in the process of paramentation and department, with the purpose of avoiding self-contamination in the surgical center. Thus, through the discussion of the crisis committee, the protocols and training were implemented linking the practice of care to continuing education. 
It is important to emphasize that the actions carried out during the pandemic have contributed to improve the practice in the assistance of health professionals before COVID-19, strengthening the multiprofessional bond. Based on this strategy, the professionals reported greater safety for the assistance in the procedures.

It is reiterated that it has been possible to describe and experience the assistance protocol, demonstrating the need for continued education and cooperation of the multidisciplinary team at this time. In this sense, the present study offers theoretical resources for the basis of training for the assistential approach, aiming at the psychological work of the workers and exposing the experience of the multidisciplinary team at this moment, in order to reflect the preventive actions in self-care during the assistential practice, reinforcing the use of protective equipment.

\section{REFERENCES}

1. Associação Brasileira de Enfermeiros de Centro Cirúrgico. SOBECC. Diretrizes de Práticas em Enfermagem Cirúrgica e Processamento de produtos para a Saúde. Práticas recomendadas. 7 ed. São Paulo; 2017, 487 p.

2. Agência Nacional de Vigilância Sanitária (ANVISA) (BR). Nota Técnica GVIMS/GGTES/ANVISA № 04/2020 [Internet]. Brasília: Ministério da saúde, 2020 [cited 2020 Apr 8]. Available from: https://www20.anvisa.gov.br/segurancadopaciente/index.php/alertas/category/covid-19

3. Ministério da Saúde (BR). Protocolo de Tratamento do novo Coronavírus (2019-nCov) [Internet]. Brasília, DF; 2020. [cited 2020 Apr 8]. Available from: https://portalarquivos2.saude.gov.br/images/pdf/2020/fevereiro/05/Protocolo-de-manejo-clinico-para-o-novo-coronavirus2019-ncov.pdf

4. Li Q, Guan X, Wu P, Wang X, Zhou L, Tong Y, et al. Early transmission dynamics in Wuhan, China, of novel coronavirus-infected pneumonia. N Engl J Med. 2020;382(13):1199-207. doi: 10.1056/NEJMoa2001316

5. Peng, PWH, Ho PL, Hota SS. Outbreak of a new coronavirus: what anaesthetists should know. Brit J Anaesthesia [Internet]. 2020 [cited 2020 Apr 8];124(5):497e501. Available from: https://bjanaesthesia.org/article/S0007-0912(20)30098-2/pdf

6. Tao KX, Zhang BX, Zhang P, Zhu P, Wang GB, Chen XP. Recommendations for general surgery clinical practice in novel coronavirus pneumonia situation. Chinese J Surg [Internet]. 2020 [cited 2020 8];58(0):E001. doi: 10.3760/cma.j.issn.0529-5815.2020.0001

7. Ti LK, Ang LS, Foong TW, Wei BS. What we do when a COVID-19 patient needs an operation: operating room preparation and guidance. Canad J Anesthesia. 2020;67:756-8. doi: 10.1007/s12630-020-01617-4

8. Alvarez JP, Bernucci F, Cabrera MC, Carrasco E, De La Fuente R. Recomendaciones para el Manejo de pacientes con COVID19 en el perioperatório. Rev Chil Anest [Internet]. 2020 [cited 2020 Apr 8];49:196-202. Available from: http://revistachilenadeanestesia.cl/PII/ revchilanestv49n02.03.pdf.

9. Fang L, Karakiulakis G, Roth M. Are patients with hypertension and diabetes mellitus at increased risk for COVID-19 infection? Lancet Resp Med [Internet]. 2020 [cited 2020 Apr 8];8(4):e21. Available from: https://www.ncbi.nlm.nih.gov/pmc/articles/PMC7118626/pdf/main.pdf

10. Wax RS, Christian MD. Practical recommendations for critical care and anesthesiology teams caring for novel coronavirus (2019-nCoV) patients [Internet]. Canad J Anesthesia. 2020;67:568-76. doi: 10.1007/s12630-020-01591-x 